\title{
Nitrogen removal from a riverine wetland: a field survey and simulation study of Phragmites japonica
}

\author{
Sinkyu Kang a, Hojeong Kang ${ }^{b, *}$, Dongwook Ko a , Dowon Lee ${ }^{\text {a }}$ \\ a Department of Environmental Planning, Graduate School of Environmental Studies, Seoul National University, \\ Seoul 151-742, South Korea \\ ${ }^{\mathrm{b}}$ Department of Environmental Science and Engineering, Ewha Institute of Science and Technology, Ewha Womans University, \\ Seoul 120-750, South Korea
}

Received 15 June 2001; received in revised form 28 November 2001; accepted 1 December 2001

\begin{abstract}
Because Phragmites japonica is one of the dominant plant species in riverine wetlands in South Korea, we constructed an individual-based plant growth model to determine management strategies for maximizing nitrogen removal by $P$. japonica for water quality improvement purposes. We calibrated our model using field data on the growth, reproduction, and mortality of P. japonica individuals collected over one growing season in 1997 (May-October). The model effectively predicted seasonal changes in the number of the individuals $\left(r^{2}=0.89\right)$, aboveground biomass $\left(r^{2}=0.85\right)$, and nitrogen concentration $\left(r^{2}=0.91\right)$. Total nitrogen, however, was poorly explained by our model $\left(r^{2}=0.53\right)$. To evaluate the effects of biomass removal (e.g. harvest or grazing) on Phragmites management strategies, removal was simulated by manipulating the intensity and period of biomass loss. Distinct patterns in population density and biomass were produced in intensity-period phase planes, suggesting that population dynamics are influenced by a strong relationship between disturbance intensity and period. In addition, the highest rates of nitrogen removal by $P$. japonica occurred for high-density populations that maintained relatively low biomass levels. (C) 2002 Elsevier Science B.V. All rights reserved.
\end{abstract}

Keywords: Individual-based plant growth model; Disturbance simulation; Nitrogen removal; Harvest intensity and period; Wetland

\section{Introduction}

Riverine wetlands delineate the interface between lotic and terrestrial ecosystems (Haycock et al., 1996), and influence the structure of both aquatic and upland communities. In stream eco-

\footnotetext{
* Corresponding author. Tel.: + 82-2-3277-3916; fax: + 822-3277-3275.

E-mail address: hjkang@mm.ewha.ac.kr (H. Kang).
}

systems, riverine wetland vegetation can affect key functional processes, including nutrient-transformations, moderation of stream water temperature, reduction of sediment input, organic matter supply to lotic communities, and stream bank stabilization (Peterjohn and Correll, 1984; Osborne and Kovacic, 1993). In particular, the ability of riparian vegetation to remove agriculturally derived nitrogen inputs from upland areas is of great importance in preventing the eutrophication of aquatic ecosystems. 
Two major mechanisms decrease mineral nitrogen inputs from water passing through riverine wetlands. Denitrification removes inorganic nitrogen permanently from the system by transforming mineral nitrogen into a gaseous state (Groffman, 1994). In addition, inorganic nitrogen inputs are temporarily attenuated through plant uptake and immobilization in plant biomass. Since nitrogen could be re-released through the decomposition of senescent plant material at the end of the growing season (in sensu Kang et al., 1998), more permanent removal of nitrogen can be achieved by removing plant material through management practices that include harvesting or grazing. The intensity and period of harvesting or grazing are related to disturbance effects on plant population dynamics and are also coupled with seasonal changes in environmental conditions. To maximize the biological removal of nitrogen using vegetation, it is crucial to understand plant population dynamics and the mechanisms of nutrient flux between soil and vegetation.

While Phragmites japonica is one of the dominant plant species in riverine wetlands in Korea, this genus has an extensive global distribution with various species of Phragmites commonly found in many wetlands worldwide. Recent studies have shown that Phragmites spp. effectively retain nitrogen in various wetland ecosystems. In restored wetlands dominated by Phragmites, 66$100 \%$ of inorganic nitrogen inputs were removed by the vegetation (Romero et al., 1999). Comparable high rates of nitrogen retention were also reported for Phragmites spp.-dominated wetlands in Mediterranean, continental, and tropical climates (Ennabili et al., 1998; Xu et al., 1999; Billore et al., 1999). While some studies have reported the physiological uptake and partitioning of nitrogen for Phragmites spp. under different environmental conditions (e.g. oxygen level, light intensity) (Hirose and Werger, 1994; Yamasaki et al., 1992), few studies have addressed more permanent strategies for nitrogen removal using harvesting or grazing techniques. In this study, we developed an individual-based plant growth model to assess the effects of biomass removal (i.e. harvesting, grazing) on the population dynamics of $P$. japonica. Field observations were used to initialize model parameters and verify the model. The effects of biomass removal on plant population dynamics were simulated by varying the intensity and duration of disturbance events in the model. Results from the model simulations were then used to determine the disturbance regimes (or management strategies) that would most effectively remove nitrogen from riverine wetlands.

\section{Materials and methods}

\subsection{Site description}

Our study site is located on the upper reach of Sagimack Stream near the Paldang Reserve in Korea $\left(37^{\circ} 30^{\prime} \mathrm{N}, 127^{\circ} 30^{\prime} \mathrm{E}\right)$. The wetland lies in a montane valley and experiences frequent inundation. The site receives approximately $1250 \mathrm{~mm}$ of precipitation annually, with the highest levels of precipitation occurring from mid-June to lateJuly. The sampling site $\left(400 \mathrm{~m}^{2}\right)$ is dominated by $P$. japonica and interspersed with a few individuals of Salix spp.

Total aboveground biomass of $P$. japonica was sampled in triplicate using $25 \mathrm{~cm} \times 25 \mathrm{~cm}$ quadrats. Sampling was conducted monthly from May to October 1997. Each sample was dried at $80{ }^{\circ} \mathrm{C}$ for $48 \mathrm{~h}$ to determine total dry mass. Stem lengths were also measured on dried individuals. Sub-samples of the dried plant material were ground using a mortar and pestle. The sub-samples were digested for total Kjeldahl nitrogen (TKN) and measured using an auto analyzer (Alpkem, Perstorp Analytical Inc.). Seeds were sampled separately from late August to October 1997 and were processed as described above. In addition to plant sampling, soil cores $(0-15 \mathrm{~cm}$ depth) were collected to determine concentrations of $2 \mathrm{M} \mathrm{KCl}$-extractable $\mathrm{NO}_{3}^{-}$and $\mathrm{NH}_{4}^{+}$.

\subsection{Model development}

An individual-based growth model for $P$. japonica was developed by incorporating growth, mortality, reproduction and nutrient dynamics of $P$. japonica individuals. This species reproduces 
both vegetatively and by seed. Vegetative spread typically occurs throughout the growing season while seed production occurs at the end of the growing season. Because these characteristics make it difficult to model the population dynamics of $P$. japonica using compartment modeling techniques, we developed an individual-based model to connect individual processes with the processes of higher organizational levels (Friend et al., 1997; Bossel, 1996; Levine et al., 1993; DeAngelis and Gross, 1992). This approach allows us to assess vegetation dynamics occurring at a population or an ecosystem level by using data observed at an individual level.

The model itself is composed of two levels (Fig. 1). The first level corresponds with individual-level processes such as photosynthesis, respiration, litter production, allocation of photosynthate, nitrogen uptake, reproduction, growth, and mortality. The higher level represents population-level processes such as recruitment rate, extinction rate, and population density.

Summaries of the mathematical equations and model parameters are given in Tables 1 and 2, respectively. We initialized model parameters using field data. Minimum requirement for a new shooting (req) was derived from the lowest weight of any individual early in the growing season. Average nitrogen concentrations for the last three months of the growing season calculated as the required nitrogen for producing onekilogram biomass (tn_req). Maximum nitrogen

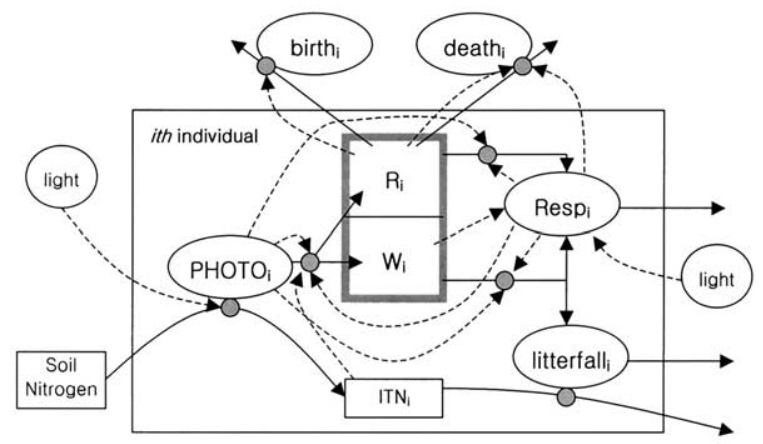

Fig. 1. A schematic diagram of the model.
Table 1

Concise mathematical representations on individual and population processes of the plant growth model.

When photosynthesis $\geq$ respiration

$\frac{\mathrm{dR}_{\mathrm{i}}}{\mathrm{dt}}=$ res_ratio $\times \frac{\mathrm{TN}_{\mathrm{i}}}{\mathrm{tn}_{-} \max } \times\left(\mathrm{PHOTO}_{\mathrm{i}}-\mathrm{RESP}_{\mathrm{i}}\right)-$ offspring $_{\mathrm{i}}$

$\frac{\mathrm{dW}_{\mathrm{i}}}{\mathrm{dt}}=\left(1-\right.$ res_ratio $\left.\times \frac{\mathrm{TN}_{\mathrm{i}}}{\mathrm{tn}_{-} \text {max }}\right) \times\left(\right.$ PHOTO $\left._{\mathrm{i}}-\mathrm{RESP}_{\mathrm{i}}\right)$

$\frac{\mathrm{dITN}_{\mathrm{i}}}{\mathrm{dt}}=\mathrm{tn}_{-}$req $\times$PHOTO $_{\mathrm{i}}-\mathrm{TN}_{\mathrm{i}} \times$ offspring $_{\mathrm{i}}$

When photosynthesis $<$ respiration

$\frac{\mathrm{dR}_{\mathrm{i}}}{\mathrm{dt}}=\mathrm{PHOTO}_{\mathrm{i}}-\mathrm{RESP}_{\mathrm{i}}-$ offspring $_{\mathrm{i}}$

$\frac{\mathrm{dW}_{\mathrm{i}}}{\mathrm{dt}}=$ fall_rate $\times \mathrm{W}_{\mathrm{i}}$

$\frac{\mathrm{dITN}_{\mathrm{i}}}{\mathrm{dt}}=\mathrm{tn}_{-}$req $\times \mathrm{PHOTO}_{\mathrm{i}}-\mathrm{TN}_{\mathrm{i}} \times$ offspring $_{\mathrm{i}}-\mathrm{TN}_{\mathrm{i}} \times$

fall_rate $\times \mathrm{W}_{\mathrm{i}}$

PHOTO $_{\mathrm{i}}=$ photo_rate $\times$ light $_{\mathrm{i}} \times \mathrm{W}_{\mathrm{i}} \times \frac{\mathrm{TN}_{\mathrm{i}}}{\text { tn_req }_{-}}$
RESP $_{\mathrm{i}}=a \times$ light $_{\mathrm{i}} \times \mathrm{W}_{\mathrm{i}}^{\mathrm{b}}$

offspring $_{\mathrm{i}}=$ birth $_{\mathrm{i}} \times\left[\left(1+\right.\right.$ random $\left._{\mathrm{i}}\right) \times$ req $]$

$\mathrm{TN}_{\mathrm{i}}=\frac{\mathrm{ITN}_{\mathrm{i}}}{\mathrm{dD}_{\mathrm{i}}+\mathrm{R}_{\mathrm{i}}}$

$\frac{\mathrm{dD}_{\mathrm{i}}}{\mathrm{dt}}=\Sigma\left(\right.$ birth $_{\mathrm{i}}-$ death $\left._{\mathrm{i}}\right)$

birth $_{\mathrm{i}} \quad=0$ for $\mathrm{R}_{\mathrm{i}}<2 \times$ req

$=1$ for $\mathrm{R}_{\mathrm{i}} \geq 2 \times$ req

death $_{\mathrm{i}}$

$=0$ for $\mathrm{R}_{\mathrm{i}} \geq$ death_tol $\times \mathrm{RESP}_{\mathrm{i}}$

$=1$ for $\mathrm{R}_{\mathrm{i}}<$ death_tol $\times \mathrm{RESP}_{\mathrm{i}}$

concentration (tn_max) and the initial population density were estimated from the nitrogen concentration and density of $P$. japonica at the beginning of the growing season. The remaining model parameters were similarly calibrated using field data.

\subsubsection{Plant production, allocation, and mortality}

The daily rate of photosynthesis $\left[\operatorname{PHOTO}_{\mathrm{i}}(\mathrm{t})\right]$ is calculated on the basis of plant biomass, plant nitrogen concentration, and a normalized light intensity that varies sinusoidally from 0 to 1 (maximum in mid-July). Plant respiration $\left[\operatorname{RESP}_{\mathrm{i}}(\mathrm{t})\right]$ is a function of plant biomass and light intensity, and follows the power law of metabolism. Plant biomass remains constant when daily photosynthesis equals daily respiration. When photosynthesis is greater than respiration, the surplus photosynthate $\left(\left[\mathrm{PHOTO}_{\mathrm{i}}(\mathrm{t})\right]-\right.$ 
$\left.\left.\operatorname{RESP}_{\mathrm{i}}(\mathrm{t})\right]\right)$ is allocated to the synthesis of new tissues $\left[\mathrm{W}_{\mathrm{i}}(\mathrm{t})\right]$ and a reservoir $\left[\mathrm{R}_{\mathrm{i}}(\mathrm{t})\right]$. The reservoir $\left[\mathrm{R}_{\mathrm{i}}(\mathrm{t})\right]$ is maintained at a certain level at all times, and is used to supply energy for reproduction, control establishment and mortality. When photosynthesis is less than respiration, growth ceases, and the reservoir is used to fuel both maintenance respiration and the initiation of senescence. When the reservoir is larger than the minimum photo-

Table 2

Variables (a) and parameters (b) used in the vegetation growth model

\begin{tabular}{|c|c|c|}
\hline (a) Variable & Unit & Description \\
\hline $\mathrm{W}_{\mathrm{i}}$ & $\mathrm{kg}$ & $\begin{array}{l}\text { Leaf and stem } \\
\text { biomass }\end{array}$ \\
\hline $\mathrm{R}_{\mathrm{i}}$ & $\mathrm{kg}$ & Reservoir biomass \\
\hline $\mathrm{PHOTO}_{\mathrm{i}}$ & $\operatorname{kgday}^{-1}$ & Daily photosynthesis \\
\hline $\operatorname{RESP}_{\mathrm{i}}$ & $\operatorname{kgday}^{-1}$ & Daily respiration \\
\hline $\operatorname{ITN}_{\mathrm{i}}$ & $\mathrm{N} g$ & $\begin{array}{l}\text { Nitrogen content of } \\
\text { individual }\end{array}$ \\
\hline $\mathrm{TN}_{\mathrm{i}}$ & $\mathrm{N} g$ plant $\mathrm{kg}^{-1}$ & $\begin{array}{l}\text { Nitrogen } \\
\text { concentration }\end{array}$ \\
\hline Offspring $_{i}$ & $\mathrm{~kg}$ & Offspring biomass \\
\hline birth $_{\mathrm{I}}$ & Unitless & $\begin{array}{l}\text { Boolean variable for } \\
\text { reproduction }\end{array}$ \\
\hline Death $_{i}$ & Unitless & $\begin{array}{l}\text { Boolean variable for } \\
\text { death }\end{array}$ \\
\hline $\mathrm{D}_{\mathrm{I}}$ & Unitless & $\begin{array}{l}\text { Population density } \\
\text { per square meter }\end{array}$ \\
\hline
\end{tabular}

(b) Parameter Value

\begin{tabular}{|c|c|c|}
\hline Req & $0.0004 \mathrm{~kg}$ & $\begin{array}{l}\text { Mean weight of new } \\
\text { offspring }\end{array}$ \\
\hline tn_req & $\begin{array}{l}8 \mathrm{~N} g \text { plant } \\
\mathrm{kg}^{-1}\end{array}$ & $\begin{array}{l}\text { Required nitrogen } \\
\text { for primary } \\
\text { production }\end{array}$ \\
\hline tn_max & $\begin{array}{l}44 \mathrm{~N} g \text { plant } \\
\mathrm{kg}^{-1}\end{array}$ & $\begin{array}{l}\text { Maximum nitrogen } \\
\text { concentration }\end{array}$ \\
\hline res_ratio & 0.5 & $\begin{array}{l}\text { Maximum allocation } \\
\text { ratio to reservoir }\end{array}$ \\
\hline Photo_const & 0.006 & $\begin{array}{l}\text { Photosynthetic } \\
\text { coefficient }\end{array}$ \\
\hline A & 0.005 & Metabolic coefficient \\
\hline B & 1 & $\begin{array}{l}\text { Power constant for } \\
\text { metabolism }\end{array}$ \\
\hline fall_rate & 0.03 & Daily leaf fall rate \\
\hline death_tol & 8 & $\begin{array}{l}\text { Tolerance factor for } \\
\text { death }\end{array}$ \\
\hline Den0 & 300 & $\begin{array}{l}\text { Initial population } \\
\text { density }\end{array}$ \\
\hline
\end{tabular}

synthate requirement for a single reproductive event (i.e. $2 \times$ req), a new individual is produced and the reservoir level decreases by req. The initial value of req was calculated as the mean value from a range of randomly selected field biomass measurements collected from new individuals. Mortality occurs when the reservoir is less than the product of respiration $\left(\mathrm{RESP}_{\mathrm{i}}\right)$ and the death-tolerance constant (death_tol), and photosynthesis is less than respiration. A deathtolerance constant was introduced to prevent the survival of severely defoliated individuals. The constant was estimated by calibrating the model with field data.

\subsubsection{Plant nitrogen uptake and allocation}

To simplify the nitrogen dynamics in the model, an unlimited pool of soil nitrogen and a constant nitrogen concentration (tn_req) were assumed. Both photosynthesis and allocation of photosynthate were affected by the nitrogen content of plant $\left(\mathrm{TN}_{\mathrm{i}}\right)$. As $\mathrm{TN}_{\mathrm{i}}$ increases, photosynthesis and allocation to the reservoir increase. In this aspect, our model differs from other plant growth models that allocate less photosynthate to reproductive organs with increasing soil nitrogen availability (Running and Gower, 1991; Landsberg and Waring, 1997; Potter, 1999). This difference reflects the fact that $P$. japonica is an $r$-strategy species, while the above studies model $K$-strategy species.

\subsubsection{Disturbance simulations}

To assess the effects of biomass removal on aboveground biomass and population density, disturbance was simulated in the model by using varying degrees and durations of biomass removal. Removal intensity was varied from 5 to $90 \%$ of the aboveground biomass of each individual, and the period of biomass removal ranged from 2 to 60 days. Here, the period of disturbance represents the recurrence of removal by the days indicated. In other words, instantaneous removal of biomass occurs followed by no disturbance until the next disturbance. Population density and aboveground biomass at the end of growing season exhibited substantial variability, depending on the combination of the intensity and duration of biomass removal. 


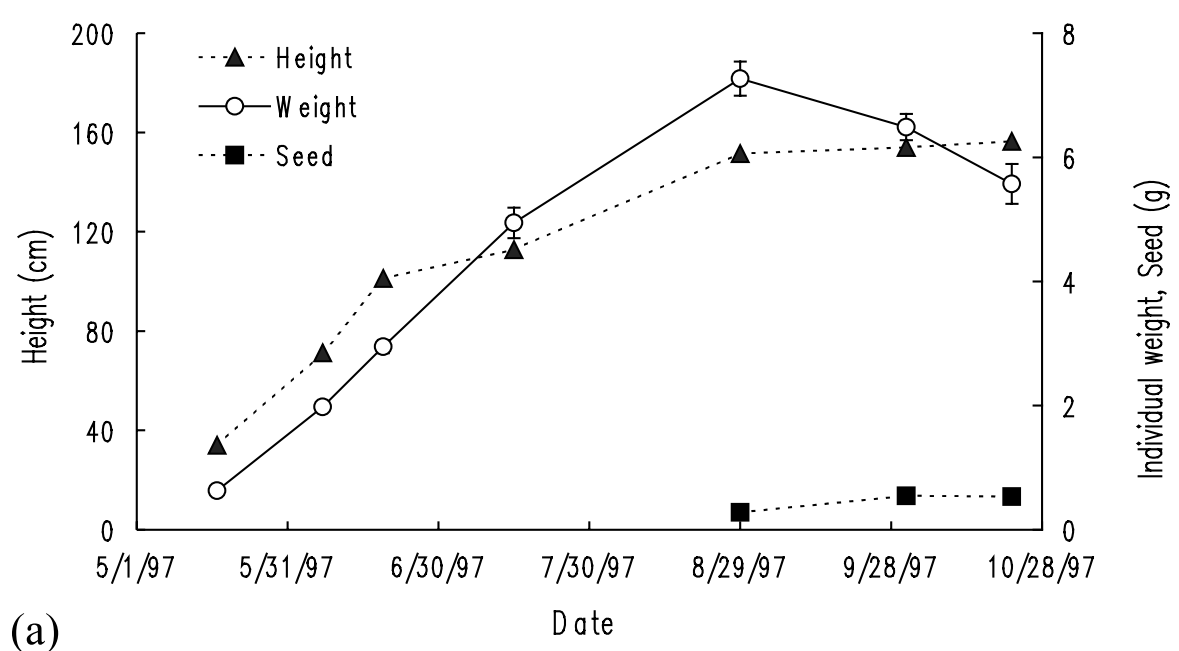

(a)

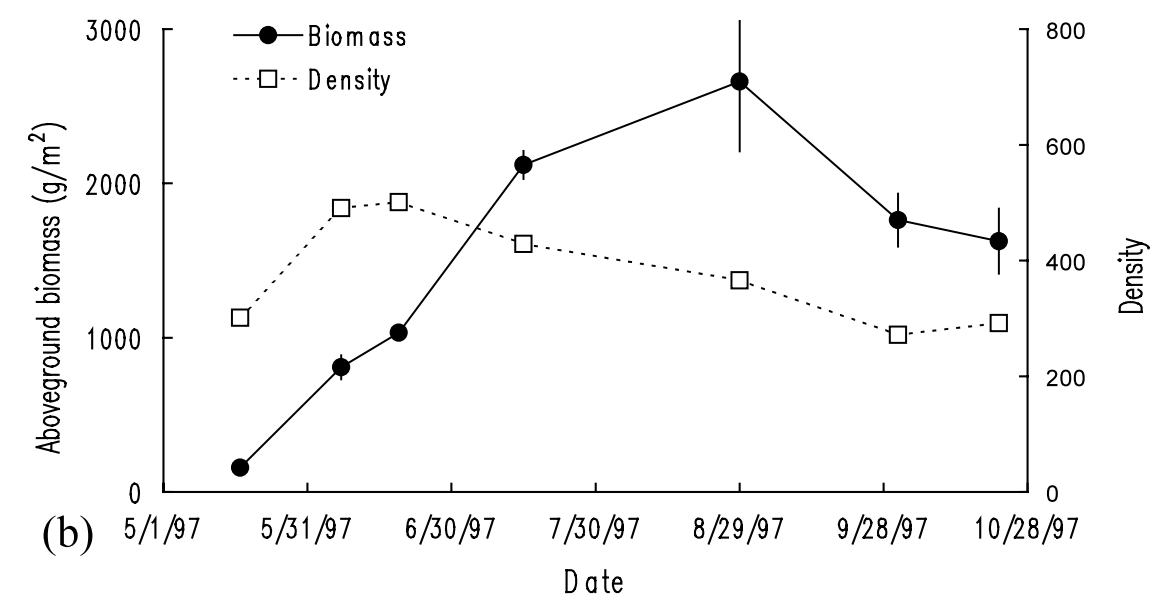

Fig. 2. Seasonal dynamics of $P$. japonica from May to October in 1997. (a) Means of individual height, biomass, and seed production and (b) total aboveground biomass and population density. Standard deviations shown $(n=3)$.

\subsection{Statistical analyses}

A regression analysis was employed to determine the relationships between model predictions and observed data of population density, above ground biomass, nitrogen content, and total nitrogen in P. japonica.

\section{Results}

\subsection{Growth and nutrient dynamics of P. japonica}

Plant heights of $P$. japonica increased early during the growing season and reached their maxima at the end of growing season. In contrast, individual plant biomass reached a maximum of $7.3 \mathrm{~g}$ during the middle of the growing season (August) and decreased afterward. Total aboveground biomass showed a similar pattern, and reached a maximum of $2.6 \mathrm{kgm}^{-2}$ (Fig. 2b). Seed production began in late August and increased up to $0.55 \mathrm{~g} \mathrm{seed}^{-1}$ by the end of growing season (Fig. 2a). Population density reached a maximum of 500 individuals $\mathrm{m}^{-2}$ early in the growing season (June) and gradually decreased to 300 individuals $\mathrm{m}^{-2}$ as the growing season ended (early October). 
To estimate individual plant biomass for modeling purposes, an allometric equation was constructed from harvested plants to determine the relationship between individual plant height and biomass. A power function estimating weight based on plant height provided the best fit with an $r^{2}=0.86\left(Y=0.0014 X^{1.69}, P<0.05, n=\right.$ 129).

\subsection{Verification}

Following parameterization, the model was used to predict changes in population density, aboveground biomass, nitrogen content, and total nitrogen of $P$. japonica during the growing season
(Fig. 3). The model effectively predicted the observed growing season patterns for population density $\left(r^{2}=0.89\right)$, aboveground biomass $\left(r^{2}=\right.$ $0.85)$, and nitrogen concentration $\left(r^{2}=0.91\right)$, and less so for total nitrogen $\left(r^{2}=0.53\right)$. Additionally, soil data showed that nitrogen concentrations reached a maximum of $44 \mathrm{~N} \mathrm{~g} \mathrm{~kg}^{-1}$ early in the growing season and decreased monotonically to 5 $\mathrm{N} \mathrm{g} \mathrm{kg}{ }^{-1}$ by the end of the growing season (Fig. $3 \mathrm{c})$. Although the predicted values of total nitrogen were poorly correlated with the observed field data, they exhibited a similar general trend over the growing season. The poor correlation may have been due to the fact that total soil nitrogen is calculated in the model as a function of the

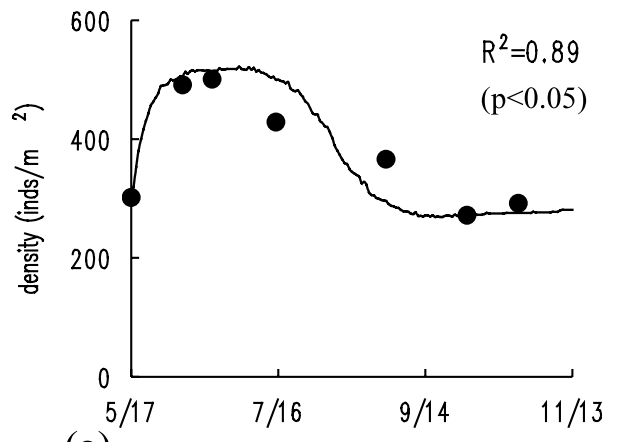

(a)

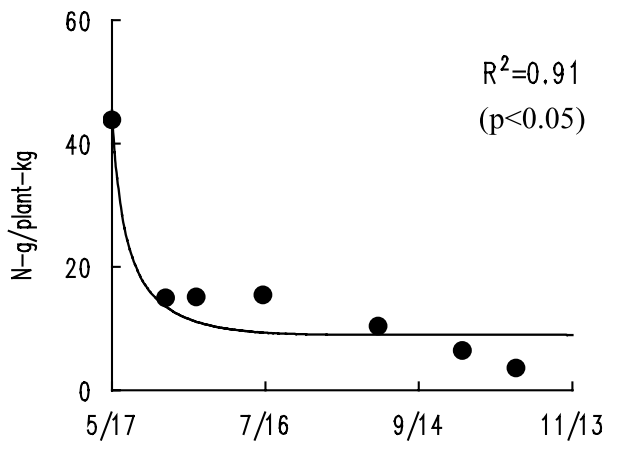

(c)

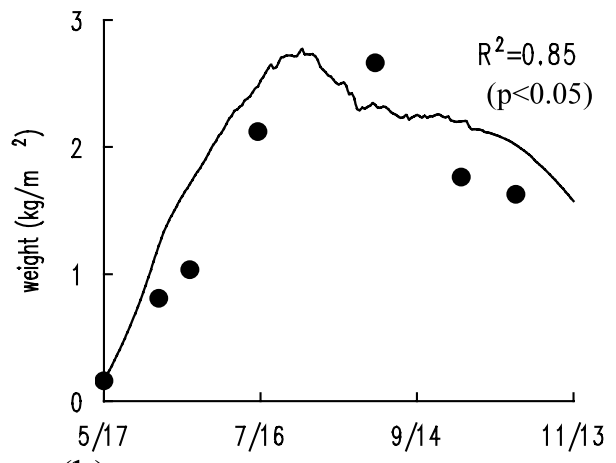

(b)

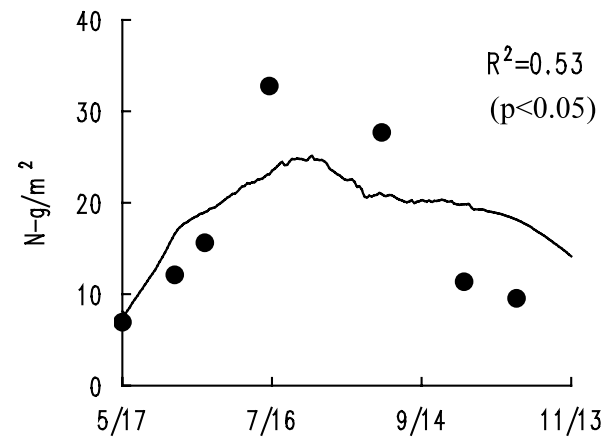

(d)

Fig. 3. Comparison between field data and the results of the calibrated model: (a) population density; (b) aboveground biomass; (c) nitrogen concentration; and (d) total nitrogen in vegetation per square meter. 
aboveground biomass and plant nitrogen concentration, and does not include any direct soil factors

\subsection{Disturbance effects on soil nitrogen removal by P. japonica}

Disturbance simulations showed that population density was positively correlated with disturbance intensity but negatively correlated with disturbance period. In contrast, aboveground biomass decreased with both decreasing removal period and increasing removal intensity. The fact that maximum density was found along the diagonal direction of the phase plane (Fig. 4a) indicated that disturbance intensity and period were coupled in their effects on population density.

The total nitrogen removed over the growing season was also mapped in the intensity-period phase space (Fig. 5). The maximum removal of nitrogen over the growing season was approximately $60 \mathrm{~N} \mathrm{~kg} \mathrm{~m}^{-2}$, and occurred as a distinct diagonal region on the phase space diagram where population density remains high but population biomass is low.

\section{Discussion}

A field survey and individual-based modeling of $P$. japonica population dynamics showed distinct seasonal patterns in population dynamics, aboveground biomass and the plant nitrogen content. Fluctuations in aboveground biomass and plant nitrogen content during the growing season exhibited a unimodal pattern and an exponential pattern respectively, similar to patterns found in a deciduous shrub (Chapin et al., 1980). Because predictions from the individual-based model, after calibration, were significantly correlated with field measurements, the model was then used to investigate the effects of disturbance (harvest or grazing) on $P$. japonica population dynamics.

The disturbance simulations showed that the conditions under which nitrogen removal from a riverine wetland soil was greatest occurred when population density was high but population
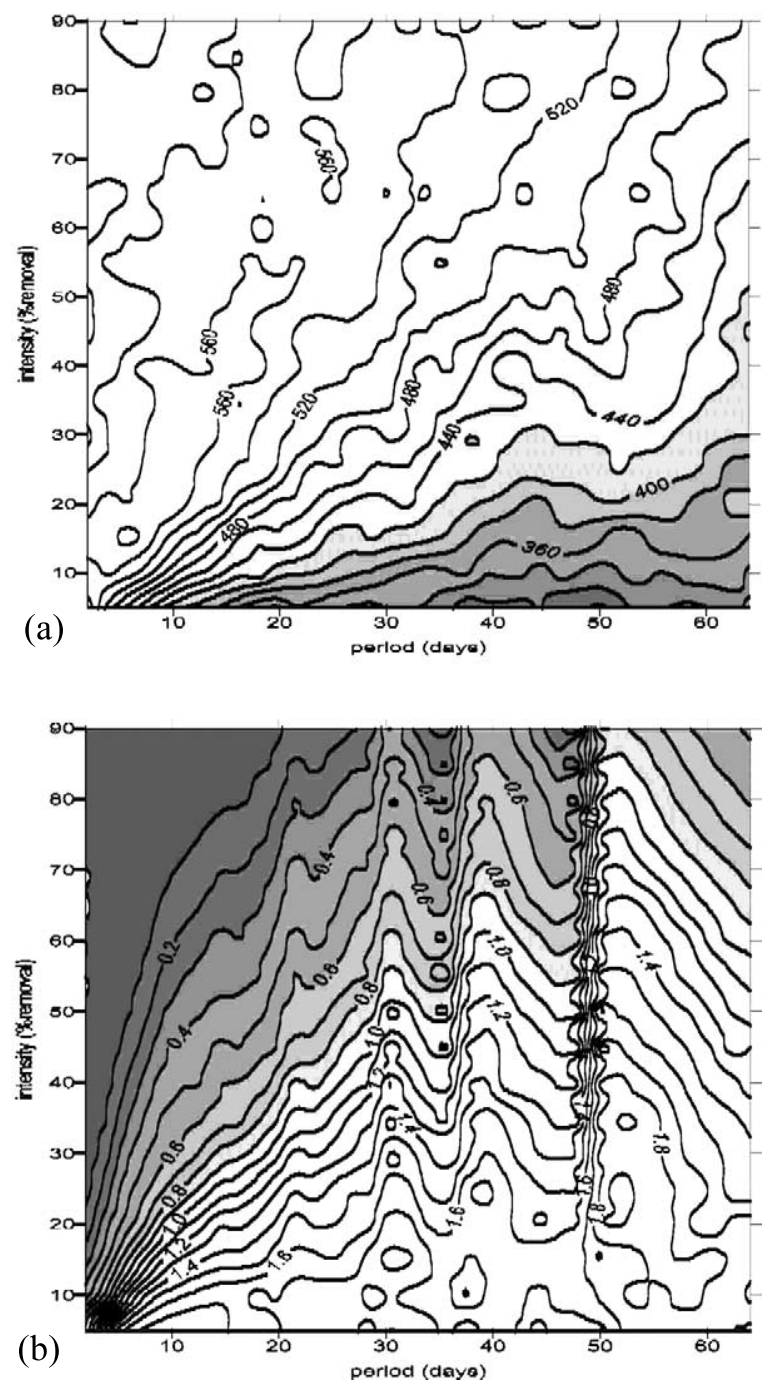

Fig. 4. Simulation results on (a) population density and (b) aboveground biomass $\left(\mathrm{kgm}^{-2}\right)$ in the harvest/grazing periodintensity phase plane.

biomass was low. In addition, our model simulations showed that nitrogen removal by $P$. japonica was influenced by both disturbance intensity and period. Our results suggest that both the intensity and duration of disturbance (i.e. biomass removal) should be considered concurrently to determine optimal vegetation management strategies for the removal of inorganic nitrogen from wetland soils.

When non-destructive harvest (i.e. harvest without affecting roots and other parts so that re- 
growth is possible) was simulated, respiration decreased exponentially but photosynthesis decreased linearly. Thus, with increasing disturbance intensity and duration, the population/individual conserves more energy by decreasing carbon losses through respiration. This suggests that the surviving individuals can compensate for biomass loss by using the energy conserved to maintain growth and reproduction.

In our simulation study, maximal nitrogen removal was occurred under the situation that maintains high population density but relatively low population biomass, both of which can be regulated by disturbances with appropriate combinations of disturbance intensity and period (Fig. $4 \mathrm{a}$ and $\mathrm{b}$ ). For example, lower respiration than photosynthesis after harvest stimulates growth and reproduction of individuals, so that it prevents the population extinct by disturbance. The relationship between harvest period and intensity for maximal nitrogen removal was found under the situations that maintain high population density but relatively low population biomass, both of which can be regulated by disturbances with appropriate disturbance intensities and periods.

If the disturbance is identified as grazing, this finding appears to support 'top-down hypothesis'

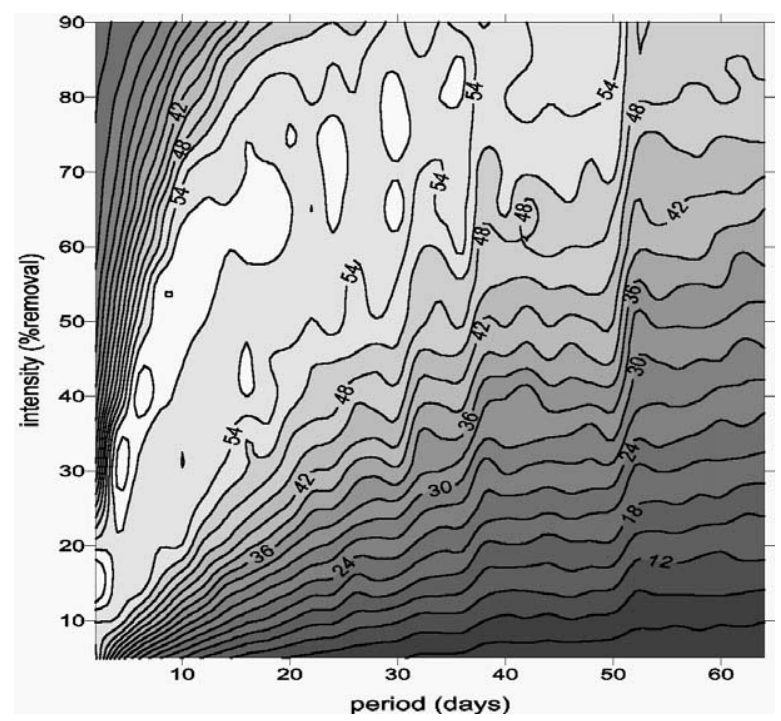

Fig. 5. Total nitrogen $\left(\mathrm{N} \mathrm{kgm}^{-2}\right)$ removed by harvest/grazing depending on the gradients of intensity and period. that insists controls of consumers on primary production (Carpenter and Kitchell, 1988; Oksanen et al., 1981; Fretwel, 1977). Our biomass removal methods could simulate biomass loss due to grazing. Because plant responses on both the individual and population levels were strongly dependent on the biomass removal treatments, our results appear to support the 'top-down' control hypothesis, which states that higher trophic levels control primary production through consumption.

Several assumptions used for simplifying the model structure may limit the application of the model to other systems. In particular, we assumed that there were no nutrient limitations or soil water deficiencies. We also did not include root respiration nor did we make any distinction between stem and leaves in the current model. However, strong correlation between our field data and model results suggest that the model could be used to simulate the effects of biomass removal on plant species of other wetland ecosystems. By readjusting the model parameters for an individual system, the model could be applied to other sites or other plant species to determine management strategies that would maximize the removal of inorganic $\mathrm{N}$ from riverine wetland soils.

\section{Acknowledgements}

S. Kang is grateful to Drs T. Oksanen, K. Neonardsson and L. Persson as well as the Swedish Institute and Daewoo Foundation for initiating and supporting this research. This work was supported by Korea Research Foundation Grant (KRF-2001-003-D00084) endowed to H. Kang. We are grateful to V. Jin for thorough revision of the manuscript and to $\mathrm{N}$. Bezzerides for valuable suggestions.

\section{References}

Billore, S.K., Singh, N., Sharma, J.K., Dass, P., Nelson, R.M., 1999. Horizontal subsurface flow gravel bed constructed wetland with Phragmites karka in Central India. Water Sci. Technol. 40, 163-171. 
Bossel, H., 1996. TREEDYN3 forest simulation model. Ecol. Model. 90, 187-227.

Carpenter, S.R., Kitchell, J.F., 1988. Strong manipulations and complex interactions: consumer control of lake productivity. Bioscience 38, 764-769.

Chapin, F.S. III, Johnson, D.A., McKendrick, J.D., 1980. Seasonal movement of nutrients in plants of differing growth from in an Alaskan tundra ecosystem: implications for herbivory. J. Ecol. 68, 189-209.

DeAngelis, D.L., Gross, T., 1992. Individual-Based Models and Approaches in Ecology: Populations, Communities and ecosystems. Chapman and Hall, New York.

Ennabili, A., Ater, M., Radoux, M., 1998. Biomass production and NPK retention in macrophytes from wetlands of the Tingitan Peninsula. Aquat. Bot. 62, 45-56.

Fretwel, S.D., 1977. The regulation of plant communities by the food chains exploiting them. Perspect. Biol. Med. 20, $169-185$.

Friend, A.D., Stevens, A.K., Knox, R.G., Cannel, M.G.R., 1997. A process-based terrestrial biosphere model of ecosystem dynamics (Hybrid v3.0). Ecol. Model. 95, 249287.

Groffman, P., 1994. Denitrification in freshwater wetlands. Curr. Top. Wetland Biogeochem. 1, 15-35.

Haycock, N., Burt, T., Goulding, K., Pinay, G., 1996. Buffer zones: their processes and potential in water protection. Proceedings of the International Conference on Buffer Zones. Quest Environmental, UK, September 1996.

Hirose, T., Werger, M.J.A., 1994. Photosynthetic capacity and nitrogen partitioning among species in the canopy of a herbaceous plant community. Oecologia 100, 203-212.

Kang, H., Freeman, C., Lee, D., Mitsch, W.J., 1998. Enzyme activities in constructed wetlands: Implication for water quality amelioration. Hydrobiologia 368, 231-235.

Landsberg, J.J., Waring, R.H., 1997. A generalised model of forest productivity using simplified concepts of radiation- use efficiency, carbon balance and partitioning. For. Ecol. Manag. 95, 209-228.

Levine, E.R., Ranson, K.J., Smith, J.A., Williams, D.L., Knox, R.G., Shugart, H.H., Urban, D.L., Lawrence, W.T., 1993. Forest ecosystem dynamics: linking forest succession, soil process and radiation models. Ecol. Model. 65, 199219.

Oksanen, L.S., Fretwell, D., Arruda, J.A., Niemela, P., 1981. Exploitation ecosystems in gradients of primary productivity. Am. Nat. 118, 240-261.

Osborne, L.L., Kovacic, D.A., 1993. Riparian vegetated buffer strips in water-quantity restoration and stream management. Freshwater Biol. 29, 243-258.

Peterjohn, W.T., Correll, D.L., 1984. Nutrient dynamics in an agricultural watershed: observations on the role of a riparian forest. Ecology 65, 1466-1475.

Potter, C.S., 1999. Terrestrial biomass and the effects of deforestation on the global carbon cycle. BioScience 49, $769-778$.

Romero, J.A., Comin, F.A., Garcia, C., 1999. Restored wetlands as filters to remove nitrogen. Chemosphere 39, 323332.

Running, S.W., Gower, S.T., 1991. Forest-BGC, a general model of forest ecosystem processes for regional applications. II. Dynamic carbon allocation and nitrogen budgets. Tree Physiol. 9, 147-160.

Xu, F.L., Tao, S., Xu, R.Z., 1999. The restoration of riparian wetlands and macrophytes in Lake Chao, an eutrophic Chinese lake: possibilities and effects. Hydrobiologia 405, 169-178.

Yamasaki, S., Kimura, M., Yoneyama, T., 1992. Early withering of lower leaves of Phragmites australis (Cav.) Trin. ex Steud. in a eutrophic stand: role of oxygen concentration, fate of nitrogen and nitrogen uptake by the plants. Aquat. Bot. 42, 143-158. 